\title{
The Clinical Genetics of Prostate Cancer
}

\author{
Sashi Kommu', Stephen Edwards', Rosalind Eeles ${ }^{3}$
}

IClinical Research Fellow, Translational Cancer Genetics Team, Institute of Cancer Research \& Medical Officer, St Anthony's Hospital, Sutton, UK; 2Stephen Edwards: Senior Scientific Officer, Translational Cancer Genetics Team, Institute of Cancer Research, Sutton, UK; ${ }^{3}$ Reader in Clinical Cancer Genetics, Translational Cancer Genetics Team, Institute of Cancer Research, Sutton, UK

Key words: hereditary, familial, prostate, cancer, genes, clinical, management

Corresponding author: Rosalind Eeles, Institute of Cancer Research, 15 Cotswold Road, Sutton, Surrey, SM2 5NG, United Kingdom,e-mail: Rosalind.Eeles@icr.ac.uk

Submitted: 19 July 2004

Accepted: 27 July 2004

\begin{abstract}
Prostate cancer is the most common cancer in men and the second highest cause of cancer-related mortality in the U.K. A genetic component in predisposition to prostate cancer has been recognized for decades. One of the strongest epidemiological risk factors for prostate cancer is a positive family history. The hunt for the genes that predispose to prostate cancer in families has been the focus of many research groups worldwide for the past 10 years. Both epidemiological and twin studies support a role for genetic predisposition to prostate cancer. Familial cancer loci have been found, but the genes that cause familial prostate cancer remain largely elusive. Unravelling the genetics of prostate cancer is challenging and is likely to involve the analysis of numerous predisposition genes. Current evidence supports the hypothesis that excess familial risk of prostate cancer could be due to the inheritance of multiple moderate-risk genetic variants. Although research on hereditary prostate cancer has improved our knowledge of the genetic aetiology of the disease, a lot of questions still remain unanswered.

This article explores the current evidence that there is a genetic component to the aetiology of prostate cancer and attempts to put into context the diverse findings that have been shown to be possibly associated with the development of hereditary prostate cancer. Linkage searches over the last decade are summarised. It explores issues as to why understanding the genetics of prostate cancer has been so difficult and why despite this, it is still a major focus of research. Finally, current and future management strategies of men with Hereditary Prostate Cancer (HPC) are discussed.
\end{abstract}

\section{Introduction}

Prostate cancer is the most common cancer in men and the second highest cause of cancer-related mortality in the U.K. Family history is the strongest risk factor for prostate cancer. A man with one close relative (such as a father or a brother) with prostate cancer has twice the risk of developing prostate cancer as a man with no family history. If two close male relatives (such as a brother and a father) are affected, a man's lifetime risk of developing prostate cancer is increased fivefold. The degree of relative risk and the increase in its magnitude can be explained by a genetic effect in, at least, a component of the predisposing factors to this disease. It is now becoming clear that the identification of mutations in candidate prostate cancer predisposition genes is proving more difficult to be made than the identification of susceptibility genes for some other common cancers such as breast, ovary, and colon cancer. 
This difficulty of prostate cancer predisposition gene identification could be for several reasons. Firstly, prostate cancer is diagnosed at a late age, thus often making it impossible to obtain DNA samples from living affected men for more than one generation. This makes linkage in large pedigrees difficult. Secondly, the presence within high-risk pedigrees of phenocopies (those with prostate cancer, but without the genetic alteration) weakens the linkage results. Finally, the genetic heterogeneity of this complex disease (the fact that different pedigrees may be due to different genes) and the uncertainty of the optimal genetic model could result in inaccurate linkage results which make gene identification difficult.

Significant linkage in familial prostate cancer was first published in 1996. A group from Johns Hopkins University, USA [1] reported linkage at a locus on chromosome 1q24-25, which was named Hereditary Prostate Cancer 1 (HPC1). Since then, several large linkage studies have been conducted, and the results of many different groups have revealed new loci and challenged others [2-5].

To date, work on prostate cancer linkage has reported genotyping data in over 1600 families. There are numerous conflicting reports reporting or refuting linkage within many areas in the genome, and this challenges our understanding of the genetic basis of this disease. This is disparate from the search for a familial breast cancer predisposition gene in which analysis of linkage in select regions revealed a site where the BRCAl gene was situated [6]. This shows that genetic predisposition to prostate cancer is highly complex probably involving numerous predisposition genes and that a high proportion of high-risk families may not be due to a single high-risk gene. Conventional linkage may not be the optimal method of predisposition gene identification in this disease because of genetic heterogeneity where different familial clusters are due to different genes.

\section{Current body of evidence for the genetic aetiology of prostate cancer}

\section{Epidemiological evidence}

In the 1950-60s, it was observed that the risk of prostate cancer in relatives of sufferers was higher [7, 8]. Large families have been observed in which prostate cancers seemed to cluster. Early observations were made in large families collected and studied in Utah $[9,10]$. To explore the evidence of a familial component, case control, cohort and twin studies have been reported.

\section{Case-control studies}

The case-control studies can be split into two simple types. The first type compares prostate cancer incidence in first-degree relatives of prostate cancer patients (cases) with the incidence in relatives of cancer-free individuals (controls). The second type compares the percentage of prostate cancer cases vs. controls with a positive family history of the disease [7-9, 11-26]. These studies indicated that the relative risks (RR) amongst first-degree relatives of affected individuals range from 0.64 to 11.00-fold [27-29]. With the exception of the RR of 0.64 [1 1], in a study which was done on a small sample set of 39 families, 15 of these 16 studies reported a RR of 1.76 or higher. The RR increases further when more than one relative is affected. Steinberg et al, 1990, [15] showed that the RR with an affected first-degree relative was 2.0, with a second-degree relative was 1.7, but with both first- and second-degree relatives combined, RR rose markedly, to 8.8 . In addition to this, they observed that the RR increased as the number of family members increased, with RRs of 2.2, 4.9 and 10.9 for 1, 2 and 3 additional affected relatives besides the proband, respectively [15]. This is all strong evidence for the involvement of a genetic component in familial disease as these increases in RR are too large to be accounted for solely by an environmental effect. Further evidence of a genetic effect is shown by the observation that the $R R$ to relatives increases as the age of the proband decreases $[9,30]$. A brother of a proband with prostate cancer at the age of 50 has a 1.9-fold higher risk of developing prostate cancer compared with a brother of a man diagnosed with the disease at the age of 70 [30].

\section{Cohort studies}

Cohort studies attempt to avoid possible bias by focussing on an unselected population. Goldgar et al [31] showed a familial prostate cancer RR of 2.21 in first-degree relatives of 6,350 probands from an unselected population from the Utah Population Database. Similarly Gronberg et al [32] found an RR of 1.70 from their study involving 5,496 sons of Swedish men from Cancer Registry data.

\section{Twin studies}

These show that there is an increased RR in monocompared with di-zygotic twins of just over 3 - to 6-fold [33]. Page et al [34] studied 15,924 male twin pairs and found pair wise concordance (twin pairs where both men were affected) rates amongst monozygotic twins was $15.7 \%$ whilst for dizygotic twins the frequency was 
$3.7 \%(p=<0.001)$. Proband wise concordance (number of concordant affected twins divided by total no of affected twins) was $27.1 \%$ for monozygotic twins and $7.1 \%$ for dizygotic twins, which gives a risk ratio of 3.8. Similar results were noted in Finland [35]. Another study concluded that up to $42 \%$ of prostate cancer risk could be attributable to heritable factors [36]. The absolute risk of prostate cancer for twins diagnosed up to the age of 75 was sixfold higher for mono- vs. di-zygotic twins $(18 \%$ vs. $3 \%)$. It also showed a statistically significant shorter time interval between age at diagnosis times for monozygotic twins compared with dizygotic twins (5.7 yrs vs. 8.8 years; $p=0.04$ ).

\section{Segregration analyses}

Segregation analyses study the structure of familial clusters and describe the mode of inheritance, age-specific cumulative risk (penetrance), and allele frequency of genetic predisposition to a disease. Carter et al [30], using such analyses, suggested that prostate cancer diagnosed at $<55$ years may be due to a rare autosomal dominant highly penetrant allele which could account for up to $43 \%$ of disease in this age group and up to $9 \%$ of prostate cancer in men aged up to 85 years. Alleles for such a rare autosomal dominant gene were predicted to exist at a frequency of 0.003 and to cause a cumulative risk of disease of $88 \%$ by the age of 85 years compared with $5 \%$ for non-carriers. Other reports have reached similar conclusions, but with a commoner allele frequency and a lower penetrance of about 67\% (Gronberg et al [32], allele frequency 0.0167; Schaid et al [37], allele frequency 0.006 ). A recessive or $X$-linked model is suggested by some studies which noted higher risks to brothers of prostate cancer cases compared with fathers $[38,39]$. Ewis et al (2002) [40] report an odds ratio of $2.04(p=0.02)$ for allele $C$ of $d Y_{s} 19$ in Japanese prostate cancer patients, whilst other alleles of this region were protective (allele $D, O R 0.26 p=0.002$ ). The $Y$ chromosome (father to son transmission) is therefore also implicated. It is possible that a mixture of several models exist giving rise to age-related risks [41]. Dominantly inherited risk allele(s) may explain early onset disease and a recessive or X-linked model could account for its later onset [42].

\section{Molecular analysis evidence - linkage studies [genome wide scans]}

Linkage analysis involves a gene-hunting technique that looks for co-segregation of a disease in large, high-risk families, with disease-causing genetic mutations. Linkage analysis has been used to map many familial cancer loci e.g. colorectal cancer, breast/ovarian cancer, and melanoma reviewed in Eeles et al, 1996 [43]. Initially, linkage analysis narrows down the region within which a disease-causing locus may lie by analysing co-inheritance of polymorphic stretches of DNA such as microsatellite markers. The sequencing of the human genome will also make the use of single nucleotide polymorphisms (SNPs) possible and as these are more numerous than polymorphic runs of DNA sequence. These will enable denser linkage maps to be determined. Once a region of linkage is identified then candidate gene mutation analysis within the region is undertaken to identify the disease-causing mutation.

\section{Candidate gene analysis evidence - BRCA2, NBS and CHEK2 genes}

The search for genetic markers of disease susceptibility often utilizes the candidate gene approach, where a gene is targeted based on the properties and metabolic pathways of its protein product. In the early nineties, prostate cancer cases were noted to be clustered within breast cancer families [44, 45]. The RR of prostate cancer in male carriers of mutations in the breast cancer predisposition genes BRCA1 and BRCA2 is increased. The RR with respect to BRCA7 was found to be 3.33 [46] and 1.82 in a further analysis by the BCLC [47]. That of BRCA2 was found to be 4.65 . The RR is higher in men with prostate cancer diagnosed before 65 years (RR 7.33), with an estimated cumulative incidence by the age of 70 of $7.5-33.0 \%$. A founder mutation 999 del 5 in BRCA2 has been identified in Iceland. This mutation is reported to confer a cumulative prostate cancer risk to carriers of $7.6 \%$ by the age of 70 [48]. Sixty seven percent of men who had the mutation all developed advanced prostate cancer and a high mortality [49], raising the possibility that BRCA2 predisposes to more aggressive disease. A report in a Swedish family carrying the BRCA2 mutation 6051 delA [50] adds weight to the evidence that such mutations are pathogenic. A mutation screen of BRCA1 and BRCA2 genes was conducted by Gayther et al [51] in a set of 38 UK families. Two germline deleterious BRCA2 mutations were observed. A further study was conducted by Edwards et al [52] on 263 men aged $<55$ at diagnosis. The six pathogenic mutations found were interestingly outside the ovarian cancer cluster region in the gene, implying a genotype/phenotype correlation and accounted for $2 \%$ of prostate cancer at this young age. This equated to an RR of 23 by the age of 60 and conferred an absolute risk of prostate cancer 
by the age of 55 of $1.3 \%$ and $10 \%$ by the age of 65 . This supports the claim that BRCA2 is a high-risk prostate cancer gene. Two recent studies have reported an increased risk of prostate cancer associated with the Ashkenazi founder mutations in the BRCA genes, lending further evidence to these data $[53,54]$.

Subsequent to these reports, germline mutations have been found in the NBS gene in the Slavic population at a higher frequency in prostate cancer cases than controls [55] and in the CHEK2 gene [56]. This raises the possibility that prostate cancer predisposition may in some cases be due to mutations in genes in the DNA repair pathway that in the homozygous form give rise to a severe phenotype (in the case of BRCA2 this would be Fanconi's anaemia D2 and in the case of NBS would be Nijmegen Breakage Syndrome), but in the heterozygous form, would give a risk of prostate cancer.

\section{Genome searches in prostate cancer}

The process of running a large number of microsatellites - typically in the region of 400, has many terms: Genome wide Scan, Genome wide Search or Genome wide Screen - and can conveniently be abbreviated to GWS. Numerous linkage analysis experiments have been undertaken across the genome to identify prostate cancer susceptibility loci. The ACTANE (Anglo-Canadian-Texan-Australian-Norwegian-EU Biomed) group has used a definition of age at onset and number of cases, but has also concentrated on the collection of clinically significant disease. This is because the disease manifests 10 years later on average than PSA-detected disease and therefore men with early onset clinically detected disease would have had a raised PSA level at even earlier age and may therefore be enriched for genetic predisposition [28].

Thus far, several GWS have been reported for prostate cancer. [1, 3, 5, 57-72]. The significant results are summarised as follows:

1q23-24: HPCl and the RNASEL data. The first GWS identified a locus named HPC 1 (Hereditary Prostate Cancer 1) at 1q24-25. A group from Johns Hopkins University, Baltimore, conducted the study in 91 North American and Swedish families and their report suggested that $34 \%$ of families may be linked to this locus [1]. Various groups have since either confirmed [73-76], or refuted [57, 58, 60, 64, 77, 78] the original observation. Goode et al [64], and Goddard et al [79] found evidence of linkage in families with more aggressive prostate cancer.

A meta analysis conducted by $X_{U}$ et al [80] representing many groups, comprising the International
Consortium for Prostate Cancer Genetics (ICPCG), reported data obtained on 772 families and found that a lower estimate of $6 \%$ of all families were linked to 1q24-25. A more refined analysis concluded that HPC 1 may play a role in a subset of families with numerous young onset cases, particularly among black men. Carpten et al [81] subsequently found mutations in the cell proliferation and apoptosis regulating gene RNASEL which was in this region. Of 8 families that were linked to the $1 \mathrm{q}$ region, two had germline mutations, one was a stop Glu265Ter (E265X) termination codon but the other was a missense mutation. Neither segregated with the disease. Some, but not all further reports have shown RNASEL mutations to be associated with prostate cancer, but with a much lower relative risk than would be predicted by the linkage evidence. Rokman et al [82] showed that the Glu265X in RNASEL was present 4.5fold more often in affected family members compared with controls. Other groups have found that RNASEL may confer much smaller prostate cancer risks or have found no mutations at all in prostate cancer cases, therefore it is not a highly penetrant prostate cancer gene which is in conflict with the linkage evidence $[83,84]$. This suggests that the linkage results are misleading or that a highly penetrant HPCl exists but is still to be found.

Other loci and candidates from GWS. Other loci follow a similar pattern as described above i.e. loci are identified that have significant LOD scores and candidate genes have mutations described therein which are then refuted, or whose risks fall on further detailed scrutiny $[85,86]$.

\section{Other significant loci:}

PCaP (1 q42.2-43; Berthon et al [57]) - this was a locus identified in the German/French population, but not confirmed by other groups. CAPB (1 p36; Gibbs et al. [59]) - a locus associated with primary brain tumour and prostate cancer which on further analysis was probably more associated with young onset prostate cancer rather than brain tumour [87]. A locus has been described on chromosome $16 q$ in sibling pairs by Suarez et al [58], and one on 20q (HPC20) by Berry et al [63]. These are still to be confirmed. A further locus has been described on the long arm of chromosome X (HPCX; Xq27-28) by Xu et al [88]). This has been confirmed by some other groups, but the gene has not yet been identified. There are also loci that have been found to be associated with more aggressive disease e.g. 7q, 19q [89-91]. Eight GWS have been published recently in one issue of the Prostate (ACTANE Consortium [72]; Lange et al [65]; Schleutker et al [66]; Cunningham et al [67]; Xu et al [68]; Wiklund et al 
[69]; Janer et al [70]; Witte et al [71], Dec 2003). A summary of these was published in an accompanying review by Easton (2003) [5]. The conclusion of these GWS to date is that there are numerous loci suggested by the GWS from various groups which are not consistently replicated by independent groups on study of further prostate cancer families. This implies that there is considerable genetic heterogeneity.

Low penetrance genes. The possibility that a disease is due to a combination of low penetrance, more common genetic variants may be entertained when large families are rare and it is difficult to locate predisposition genes by linkage. Candidate studies of polymorphisms are presently underway in prostate cancer and there is currently no uniform pattern of polymorphisms which confers increased risk from the data. However, the most consistent polymorphisms to date that confer a moderately increased risk are in the SRD5A2, GSTP1 and the AR genes, [92-102].

\section{Optimising prostate cancer predisposition gene discovery in the near future - issues to be addressed}

The are several uncertainties in the area of genetic predisposition which are currently taxing researchers in this area. These include (a) what is the optimal genetic model? (b) are there different predisposition genes in different populations? and (c) how much agreement is there between various groups for the putative loci? The results of future large scale multicentre studies will potentially answer these questions.

Combining data. It is possible that the studies undertaken thus far are underpowered, and pooling of data may improve the chances of finding the true underlying linkage. This is the aim of the creation of groups such as ICPCG. Groups undertaking linkage analyses worldwide collaborate within this consortium. In 2000 , via a meta-analysis, this group found that the 1q24 locus may contribute to about $6 \%$ of prostate cancer families and was more common in larger prostate cancer clusters whose average age of onset was $<65$ years [80].

Clinical vs. Screen Detected Disease. Current data suggest that progression to clinical disease is more likely following a raised PSA and occurs a median time of 10 years after the PSA has risen [103]. In theory, patients in families that are diagnosed with clinically detected disease may have different genes to those involved in PSA screen detected patients. At present, whether this is true, this is unknown.
Genetic heterogeneity for linkage: more than one prostate cancer predisposition gene. The fact that $2 \%$ of early onset cases have deleterious mutations in the BRCA2 gene and that a further small percentage is due to NBS and CHEK2 mutations and yet models suggest that up to $43 \%$ of such cases may harbour a predisposition gene [30], indicates that there are further prostate cancer susceptibility genes to be discovered.

Many instead of one prostate cancer predisposition gene per family. In an age when the majority of monogenic human disease genes have been identified, a particular challenge for the coming generation of human geneticists will be resolving complex polygenic and multifactorial diseases. It is likely that the majority of genetic predisposition to prostate cancer will follow this model.

\section{Current clinical management concepts in hereditary prostate cancer}

The question of whether a genetic change influencing prostate cancer causation is associated with factors altering treatment response needs to be addressed. Recent reports are conflicting. Carefully documented multi-institutional, prospective family history data collection and outcome analysis are vital to optimising our understanding of this condition. The current management issues surrounding hereditary prostate cancer (HPC) involve several components: (i) the degree of biological aggressiveness of HPC, (ii) whether HPC is an independent predictor of treatment outcome, (iii) whether there is a difference in the survival curves between sporadic and HPC and (iv) the outcome patterns in those patients treated with radical prostatectomy vs. radiotherapy by family history.

\section{Determining the degree of biological aggressiveness}

Walsh initially observed that there was no significant difference between phenotypes of sporadic, familial and HPC undergoing radical prostatectomy with respect to clinical stage, pre-op PSA, PSA density, prostate weight, Gleason score, pathologic stage or tumour histology [104]. This was later challenged by the observation that patients with localized prostate cancer who reported a positive family history may have a worse outcome at three and five years following either radiation therapy or surgery than those with sporadic cancers [105]. This was then again refuted by three further studies which found no difference in the aggressiveness of HPC versus sporadic disease [106108]. This area therefore remains controversial. 


\section{Is HPC an independent predictor of treatment outcome?}

Kupelian et al [108] first demonstrated that the presence of a family history of prostate cancer correlates with treatment outcome in a large unselected series of patients and suggested that familial prostate cancer may have a more aggressive course than nonfamilial prostate cancer. Further studies are currently underway to validate this finding.

\section{Survival differences between sporadic and HPC}

No significant differences in either overall or cause-specific survival were found between sporadic, familial, and HPC patients [109]. At present it seems plausible that treatment plans should not differ based on presence or absence of familial prostate cancer, but further work is needed to substantiate this.

\section{Should men with a family history of prostate cancer be treated rather than observed?}

Based on the current body of evidence there seems to be a rationale for genetic screening of men at risk once genes responsible for prostate cancer are identified. The American Urological Association recommends that men who are at high risk for developing prostate cancer such as men with a family history of the disease, or men of African-American descent begin receiving routine prostate cancer screening at the age of 40 [110]. The American Cancer Society recommends that men receive PSA or digital rectal examination testing annually at the age of 50 , or earlier if they have a family history of the disease or are of African-American descent [ [1 111$]$.

\section{Outcome patterns in HPC men treated with radiotherapy vs. radical prostatectomy}

Hanlon et al [112] found no difference in biochemical failure rates between carefully matched men with and without a family history of prostate cancer. This supports other studies that failed to show an increased risk of failure after definitive therapy for clinically localized prostate cancer in men with either combined hereditary and familial and patients with the sporadic form of prostate cancer.

\section{Chemoprevention trials}

Prostate cancer chemoprevention is the administration of agents that inhibit one or more steps in prostatic carcinogenesis. The main components of chemoprevention include agents and their molecular targets, strategic intermediate endpoint biomarkers and their critical pathways and cohorts identified by genetic and acquired risk factors [1 13]. The identification of genetic susceptibility loci would enable a group of men at high risk of developing prostate cancer to be identified to serve as subjects for chemoprevention trials. If such trials yield positive results, they potentially could lead to a recommendation for preventative therapy in genetic mutation carriers. Several putative chemopreventive agents are currently being investigated. Results of a population-based, randomized phase III trial demonstrates that finasteride may prevent prostate cancer. However, the paper suggested that only low grade tumours were prevented and in fact the number of high grade tumours was greater in the finasteride arm. Clarke et al [1 14] studied the impact of supplemental dietary selenium on the change in the incidence of prostate cancer. They found that although selenium shows no protective effects against the primary study endpoint of squamous and basal cell carcinomas of the skin, the selenium-treated group in their series had substantial reductions in the incidence of prostate cancer as a secondary endpoint. Further studies are clearly indicated. Preliminary data seem to suggest at least some benefit with the use of other agents as potential preventatives in addition to selenium. These include vitamin $E$, vitamin $D$, other 5 -alpha-reductase inhibitors, cyclooxygenase-2 inhibitors, lycopene, and green tea. Some of these agents are being tested in new large-scale phase III clinical trials [1 15]. The Selenium and Vitamin E Cancer Prevention Trial (SELECT), is an intergroup phase III clinical trial designed to test the efficacy of selenium and vitamin $\mathrm{E}$ alone and in combination in the prevention of prostate cancer and aims to build on secondary analyses of large-scale chemoprevention trials [116]. The emergence of new powerful tools such as proteomic analysis of tissue based and secreted proteins [117] and gene chip cDNA microarrays for multiplex gene expression profiling would optimise the identification of new molecular targets, cohorts at risk and the design of suitable combination trials.

\section{Targeted screening}

Several controversies surround the management of relatives of prostate cancer patients. Targeted screening studies have shown a higher percentage of raised PSA levels in relatives of cases in families compared with sporadic cases. In a screening study of prostate cancer in high-risk families done by McWhorter et al [1 18] it was shown that previously unsuspected and clinically relevant cancers were found in $24 \%$ of a total of 34 first-degree 
relatives, compared to the approximately 1 (3\%) expected $(p<0.01)$. The study emphasized the importance of thorough screening in first-degree relatives of prostate cancer patients. The first targeted screening study based on BRCAT/2 genotype will start later this year (the IMPACT study; Tischkowitz and Eeles, 2003) [1 19]. Targeted screening can be achieved by monitoring serum PSA levels in relatives of young or early onset prostate cancer or families with multiple cases. Counselling about the uncertainties of optimal age at which screening should be initiated is of paramount importance. The sub-thirty and sub-forty year old groups would not be screened by most authorities. Most would start screening either at age five years younger than youngest age at diagnosis of a relative or forty years, but not normally younger than this.

\section{Proteomics and bioinformatics}

With the recent exponential increase in the development and improvement of techniques involving proteomics, there has been a dramatic increase in the likelihood of finding clinically relevant candidate genes, gene clusters and signalling pathways. This would potentially extrapolate itself into better diagnostic and/or more specific targeted therapeutic plans in the management of sufferers of prostate cancer $[119,120]$.

\section{Summary}

Prostate cancer inheritance following a simple Mendelian pattern may be identified in the families of probands with early-onset cases. At present, the only clinically applicable measure to try to reduce prostate cancer mortality in families with hereditary disease is screening, which aims to diagnose the disease when it is still in a curable stage. The specific mechanism of how gene mutations contribute to an increased susceptibility for prostate cancer remains elusive but the finding of germline mutations in the BRCA2, CHEK2 and NBS 1 genes suggest that at least a proportion may occur due to mutations in the DNA repair pathway. This would have implications for treatment of such individuals with DNA damaging agents. It is likely that the cause of the majority of prostate cancer cases will be multifactorial and will involve genetic and environmental factors.

\section{Acknowledgements}

SK is funded by St. Anthony's Hospital and the Prostate Cancer Charitable Trust.

SE is funded by Cancer Research UK.

RE is funded by the Institute of Cancer Research, Cancer Research UK, the Prostate Cancer Charitable Trust \& the Ronald and Rita McAulay Foundation.

\section{References}

1. Smith JR, Freije D, Carpten JD, Gronberg H, Xu J, Isaacs SD, Brownstein MJ, Bova GS, Guo H, Buinovszky P, Nusskern DR, Damber JE, Bergh A, Emanuelsson M, Kallioniemi OP, Walker-Daniels J, Bailey-Wilson JE, Beaty TH, Meyers DA, Walsh PC, Collins FS, Trent JM and Isaacs WB. Major susceptibility locus for prostate cancer on chromosome 1 suggested by a genome-wide search. Science 1996; 274 (5291): 1371-1374.

2. Eeles RA, the UK Familial Prostate Study Co-ordinating Group and the CRC/BPG UK Familial Prostate Cancer Study Collaborators. Genetic predisposition to prostate cancer. Prostate Cancer Prostatic Dis 1999; 2 (1): 9-15.

3. Ostrander EA and Stanford JL. Genetics of prostate cancer: too many loci, too few genes. Am J Hum Genet 2000; 67 (6): 1367-1375. Epub 2000 Nov 07. Review.

4. Simard J, Dumont M, Labuda D, Sinnett D, Meloche C, El-Alfy $M$, Berger L, Lees E, Labrie F and Tavtigian SV. Prostate cancer susceptibility genes: lessons learned and challenges posed. Endocr Relat Cancer 2003; 10 (2): 225-259. Review.

5. Easton DF, Schaid DJ, Whittemore AS, Isaacs WJ and the International Consortium for Prostate Cancer Genetics. Where are the prostate cancer genes? A summary of eight genome wide searches. Prostate 2003; 57 (4): 261-269.

6. Hall JM, Lee MK, Newman B, Morrow JE, Anderson LA, Huey B and King MC. Linkage of early-onset familial breast cancer to chromosome 17q21. Science 1990; 250 (4988): 1684-1689.

7. Morganti G, Gianferrari L, Cresseri A, Arrigoni G and Lovati G. Clinico-statistical and genetic research on neoplasms of the prostate. Acta Genet Stat Med 1956-1957; 6 (2): 304-305. French.

8. Woolf CM. An investigation of the familial aspects of carcinoma of the prostate. Cancer 1960; 13: 739-744.

9. Cannon L, Bishop DT, Skolnick M, Hunt S, Lyon JL and Smart CR. Genetic epidemiology of prostate cancer in the Utah Mormon genealogy. Cancer Survey 1982; 1: 47-69.

10. Cannon-Albright $L$ and Eeles RA. Progress in prostate cancer. Nat Genet 1995; 9 (4): 336-338.

11. Steele R, Lees RE, Kraus AS and Rao C. Sexual factors in the epidemiology of cancer of the prostate. J Chronic Dis 1971; 24 (1): 29-37.

12. Krain LS. Some epidemiologic variables in prostatic carcinoma in California. Prev Med 1974; 3 (1): 154-159.

13. Schuman LM, Mandel J, Blackard C, Baver H, Scarlett J and McHugh R. Epidemiologic study of prostatic cancer: preliminary report. Cancer Treat Rep 1977; 61 (2): 181-186.

14. Meikle AW, Smith JA and West DW. Familial factors affecting prostatic cancer risk and plasma sex-steroid levels. Prostate 1985; 6 (2): 121-128.

15. Steinberg GD, Carter BS, Beaty TH, Childs B and Walsh PC. Family history and the risk of prostate cancer. Prostate 1990; 17 (4): 337-347.

16. Fincham SM, Hill GB, Hanson J and Wijayasinghe C. Epidemiology of prostatic cancer: a case-control study. Prostate 1990; 17 (3): 189-206.

17. Spitz MR, Currier RD, Fueger JJ, Babaian RJ and Newell GR. Familial patterns of prostate cancer: a case-control analysis. J Urol 1991; 146 (5): 1305-1307.

18. Ghadirian P, Cadotte M, Lacroix A and Perret C. Family aggregation of cancer of the prostate in Quebec: the tip of the iceberg. Prostate 1991; 19 (1): 43-52.

19. Whittemore AS, Wu AH, Kolonel LN, John EM, Gallagher RP, Howe GR, West DW, Teh CZ and Stamey T. Family history and prostate cancer risk in black, white, and Asian men in the United States and Canada. Am J Epidemiol 1995; 141 (8): 732-740. 
20. Hayes RB, Liff JM, Pottern LM, Greenberg RS, Schoenberg JB, Schwartz AG, Swanson GM, Silverman DT, Brown LM, Hoover $\mathrm{RN}$, et al. Prostate cancer risk in U.S. blacks and whites with a family history of cancer. Int J Cancer 1995; 60 (3): 361-364.

21. Isaacs SD, Kiemeney LA, Baffoe-Bonnie A, Beaty TH and Walsh $P C$. Risk of cancer in relatives of prostate cancer probands. J Natl Cancer Inst 1995; 87 (13): 991-996.

22. Keetch DW, Rice JP, Suarez BK and Catalona WJ. Familial aspects of prostate cancer: a case control study. J Urol 1995; 154 (6): 2100-2102.

23. Lesko $S M$, Rosenberg $L$ and Shapiro $S$. Family history and prostate cancer risk. Am J Epidemiol 1996; 144 (11): 1041 -1047.

24. Ghadirian P, Howe GR, Hislop TG and Maisonneuve P. Family history of prostate cancer: a multi-center case-control study in Canada. Int J Cancer 1997; 70 (6): 679-681.

25. Glover FE Jr, Coffey DS, Douglas LL, Russell H, Cadigan M Tulloch T, Wedderburn K, Wan RL, Baker TD and Walsh PC. Familial study of prostate cancer in Jamaica. Urology 1998; 52 (3): $441-443$

26. Bratt $\mathrm{O}$, Kristoffersson U, Lundgren R and Olsson H. Familial and hereditary prostate cancer in southern Sweden. A population-based case-control study. Eur J Cancer 1999; 35 (2): 272-277.

27. Eeles RA, Dearnaley DP, Ardern-Jones A, Shearer RJ, Easton DF Ford D, Edwards S, Dowe A and 105 collaborators. Familia prostate cancer: the evidence and the Cancer Research Campaign/British Prostate Group (CRC/BPG) UK Familial Prostate Cancer Study. Br J Urol 1997; 79 Suppl 1: 8-14. Review.

28. Singh R, Eeles RA, Durocher F, Simard J, Edwards S, Badzioch $M$, Kote-Jarai Z, Teare D, Ford D, Dearnaley D, Ardern-Jones A, Murkin A, Dowe A, Shearer R, Kelly J, Labrie F, Easton D, Narod SA, Tonin PN and Foulkes WD. High risk genes predisposing to prostate cancer development-do they exist? Prostate Cancer Prostatic Dis 2000; 3 (4): 241-247.

29. Johns LE and Houlston RS. A systematic review and meta-analysis of familial prostate cancer risk. BJU Int 2003; 91 (9): 789-94. Review.

30. Carter BS, Beaty TH, Steinberg GD, Childs B and Walsh PC. Mendelian inheritance of familial prostate cancer. Proc Nat Acad Sci USA 1992; 89 (8): 3367-3371.

31. Goldgar DE, Easton DF, Cannon-Albright LA and Skolnick MH. Systematic population-based assessment of cancer risk in first-degree relatives of cancer probands. J Natl Cancer Inst 1994; 86 (21): 1600-1608.

32. Gronberg H, Damber L and Damber JE. Familial prostate cancer in Sweden. A nationwide register cohort study. Cancer 1996; 77 (1): 138-43. Review.

33. Ahlbom A, Lichtenstein P, Malmstrom $H$, Feychting $M$, Hemminki $\mathrm{K}$ and Pedersen NL. Cancer in twins: genetic and nongenetic familial risk factors. J Natl Cancer Inst 1997; 89 (4): 287-293.

34. Page WF, Braun MM, Partin AW, Caporaso N and Walsh P. Heredity and prostate cancer: a study of World War II veteran twins. Prostate 1997; 33 (4): 240-245.

35. Verkasalo PK, Kaprio J, Koskenvuo M and Pukkala E. Genetic predisposition, environment and cancer incidence: a nationwide twin study in Finland, 1976-1995. Int J Cancer 1999; 83 (6): 743-749.

36. Lichtenstein P, Holm NV, Verkasalo PK, Iliadou A, Kaprio J, Koskenvuo M, Pukkala E, Skytthe A and Hemminki K. Environmental and heritable factors in the causation of canceranalyses of cohorts of twins from Sweden, Denmark, and Finland. N Engl J Med 2000; 343 (2): 78-85.

37. Schaid DJ, McDonnell SK, Blute ML and Thibodeau SN. Evidence for autosomal dominant inheritance of prostate cancer. Am J Hum Genet 1998; 62 (6): 1425-1438.
38. Narod SA, Dupont A, Cusan L, Diamond P, Gomez JL, Suburu $R$ and Labrie F. The impact of family history on early detection of prostate cancer. Nat Med 1995; 1 (2): 99-101.

39. Monroe KR, Yu MC, Kolonel LN, Coetzee GA, Wilkens LR, Ross RK and Henderson BE. Evidence of an X-linked or recessive genetic component to prostate cancer risk. Nat Med 1995; 1 (8): 827-829

40. Ewis AA, Lee J, Naroda T, Sasahara K, Sano T, Kagawa S, Iwamoto $T$ and Nakahori Y. Linkage between prostate cancer incidence and different alleles of the human Y-linked tetranucleotide polymorphism DYS 19. J Med Invest 2002; 49 (1-2): 56-60.

41. Cui J, Staples MP, Hopper JL, English DR, McCredie MR and Giles GG. Segregation analyses of 1,476 population-based Australian families affected by prostate cancer. Am J Hum Genet 2001; 68 (5): 1207-18. Epub 2001 Apr 11.

42. Conlon EM, Goode EL, Gibbs M, Stanford JL, Badzioch M, Janer M, Kolb S, Hood L, Ostrander EA, Jarvik GP and Wijsman EM. Oligogenic segregation analysis of hereditary prostate cancer pedigrees: evidence for multiple loci affecting age at onset. Int J Cancer 2003; 105 (5): 630-635.

43. Eeles RA and Cannon-Albright L. Familial prostate cancer and its management. In: Eeles RA, Easton DF, Ponder BAJ \& Eng C (eds) 2004. Genetic Predisposition to Cancer. 2nd Edition, Arnold UK.

44. Tulinius $H$, Olafsdottir $G H$, Sigvaldason $H$, Tryggvadottir $L$ and Bjarnadottir K. Neoplastic diseases in families of breast cancer patients. J Med Genet 1994; 31 (8): 618-621.

45. Anderson DE and Badzioch MD. Familial breast cancer risks. Effects of prostate and other cancers. Cancer 1993; 72: 114-119.

46. Ford D, Easton DF, Bishop DT, Narod SA and Goldgar DE. Risks of cancer in BRCA1-mutation carriers. Breast Cancer Linkage Consortium. Lancet 1994; 343: 692-695.

47. Thompson D, Easton DF and the Breast Cancer Linkage Consortium. Cancer incidence in BRCA1 mutation carriers. J Natl Cancer Inst 2002; 94: 1358-1365.

48. Thorlacius S, Struewing JP, Hartge P, Olafsdottir GH, Sigvaldason $H$, Tryggvadottir L, Wacholder S, Tulinius H and Eyfjord JE. Population-based study of risk of breast cancer in carriers of BRCA2 mutation. Lancet 1998; 352: 1337-1339.

49. Sigurdsson S, Thorlacius S, Tomasson J, Tryggvadottir L, Benediktsdottir K, Eyfjord JE and Jonsson E. BRCA2 mutation in Icelandic prostate cancer patients. J Mol Med 1997; 75: 758-761.

50. Gronberg H, Ahman AK, Emanuelsson M, Bergh A, Damber JE and Borg A. BRCA2 mutation in a family with hereditary prostate cancer. Genes Chromosomes Cancer 2001; 30: 299-301.

51. Gayther SA, de Foy KA, Harrington P, Pharoah P, Dunsmuir WD, Edwards SM, Gillett C, Ardern-Jones A, Dearnaley DP, Easton DF, Ford D, Shearer RJ, Kirby RS, Dowe AL, Kelly J, Stratton MR, Ponder BA, Barnes D and Eeles RA. The frequency of germ-line mutations in the breast cancer predisposition genes BRCA1 and BRCA2 in familial prostate cancer. The Cancer Research Campaign/British Prostate Group United Kingdom Familial Prostate Cancer Study Collaborators. Cancer Res 2000; 60: 4513-4518.

52. Edwards SM, Kote-Jarai Z, Meitz J, Hamoudi R, Hope Q, Osin P, Jackson R, Southgate C, Singh R, Falconer A, Dearnaley DP, Ardern-Jones A, Murkin A, Dowe A, Kelly J, Williams S, Oram R, Stevens M, Teare DM, Ponder BA, Gayther SA, Easton DF, Eeles RA; Cancer Research UK/ British Prostate Group UK Familial Prostate Cancer Study Collaborators; British Association of Urological Surgeons Section of Oncology. Two percent of men with early-onset prostate cancer harbor germline mutations in the BRCA2 gene. Am J Hum Genet 2003; 72 (1): 1-12. Epub 2002 Dec 09.

53. Kirchhoff T, Kauff ND, Mitra N, Nafa K, Huang H, Palmer C, Gulati T, Wadsworth and D.S.E, Robson ME, Ellis NA and Offit K. BRCA mutations and risk of prostate cancer in Ashkenazi Jews. Clin Cancer Res 2004; 10 (9): 2918-2921. 
54. Giusti RM, Rutter JL, Duray PH, Freedman LS, Konichezky M, Fisher-Fischbein J, Greene MH, Maslansky B, Fischbein A, Gruber SB, Rennert G, Ronchetti RD, Hewitt SM, Struewing JP and Iscovich $J$. A twofold increase in BRCA mutation related prostate cancer among Ashkenazi Israelis is not associated with distinctive histopathology. J Med Genet 2003; 40 (10): 787-792.

55. Cybulski C, Gorski B, Debniak T, Gliniewicz B, Mierzejewski M, Masoic B, Jakubowska A, Zlowocka E, Sikorski A, Narod SA and Lubinski J. NBS1 is a prostate cancer susceptibility gene. Cancer Res 2004; 64 (4): 1215-1219.

56. Dong X, Wang L, Taniguchi K, Wang X, Cunningham JM, McDonnell SK, Qian C, Marks AF, Slager SL, Peterson BJ, Smith DI, Cheville JC, Blute ML, Jacobsen SJ, Schaid DJ, Tindall DJ, Thibodeau SN and Liu W. Mutations in CHEK2 associated with prostate cancer risk. Am J Hum Genet 2003; 72 (2): 270-80. Epub 2003 Jan 17.

57. Berthon P, Valerie A, Cohen-Akenine A, Drelon E, Paiss T, Wohr G, Latil A, Millasseau P, Mellah I, Cohen N, Blanche H, Bellane-Chantelot C, Demenais F, Teillac P, Le Duc A, de Petriconi R, Hautmann R, Chumakov I, Bachner L, Maitland NJ, Lidereau $R$, Vogel W, Fournier G, Mangin P, Cussenot $O$, et al. Predisposing gene for early-onset prostate cancer, localized on chromosome 1q42.2-43. Am J Hum Genet 1998; 62 (6): 1416-1424.

58. Suarez BK, Lin J, Burmester JK, Broman KW, Weber JL, Baneriee TK, Goddard KA, Witte JS, Elston RC and Catalona WJ. A genome screen of multiplex sibships with prostate cancer. Am J Hum Genet 2000; 66 (3): 933-944.

59. Gibbs M, Stanford JL, McIndoe RA, Jarvik GP, Kolb S, Goode EL, Chakrabarti L, Schuster EF, Buckley VA, Miller EL, Brandzel $S$, Li S, Hood L and Ostrander EA. Evidence for a rare prostate cancer prostate cancer-susceptibility locus at chromosome 1 p36. Hum Genet 1999; 64 (3): 776-787

60. Berry R, Schaid DJ, Smith JR, French AJ, Schroeder JJ, McDonnell SK, Peterson BJ, Wang ZY, Carpten JD, Roberts SG, Tester DJ, Blute ML, Trent JM and Thibodeau SN. Linkage analyses at the chromosome 1 loci 1q24-25 (HPC1), 1q42.2-43 (PCAP), and 1 p36 (CAPB) in families with hereditary prostate cancer. Am J Hum Genet 2000; 66 (2): 539-546.

61. Tavtigian SV, Simrad J, Teng DH, Abtin V, Baumgard M, Beck A, Camp NJ, Carillo AR, Chen Y, Dayananth P, Desrochers M, Dumont M, Farnham JM, Frank D, Frye C, Ghaffari S, Gupte JS, Hu R, lliev D, Janecki T, Kort EN, Laity KE, Leavitt A, Leblanc G, McArthur-Morrison J, Pederson A, Penn B, Peterson KT, Reid JE, Richards S, Schroeder M, Smith R, Snyder SC, Swedlund B, Swensen J, Thomas A, Tranchant M, Woodland AM, Labrie F, Skolnick MH, Neuhausen S, Rommens J and Cannon-Albright LA. A candidate prostate cancer susceptibility gene at chromosome 17p. Nat Genet 2001; 27 (2): 172-180.

62. Hsieh CL, Oakley-Girvan I, Gallagher RP, Wu AH, Kolonel LN, Teh CZ, Halpern J, West DW, Paffenbarger RS Jr and Whittemore AS. Re: prostate cancer susceptibility locus on chromosome 1q: a confirmatory study. J Natl Cancer Inst 1997; 89 (24): 1893-1894

63. Berry R, Schroeder JJ, French AJ, McDonnell SK, Peterson BJ, Cunningham JM, Thibodeau SN and Schaid DJ. Evidence for a prostate cancer - susceptibility locus on chromosome 20 . Am J Hum Genet 2000; 67 (1): 82-91. Epub 2000 May 16.

64. Goode EL, Stanford JL, Chakrabarti L, Gibbs M, Kolb S, Mclndoe RA, Buckley VA, Schuster EF, Neal CL, Miller EL, Brandzel S, Hood L, Ostrander EA and Jarvik GP. Linkage analysis of 150 high-risk prostate cancer families at 1q24-25. Genet Epidemiol 2000; 18 (3): 251-275.

65. Lange EM, Gillanders EM, Davis CC, Brown WM, Campbell JK, Jones M, Gildea D, Riedesel E, Albertus J, Freas-Lutz D, Markey C, Giri V, Dimmer JB, Montie JE, Trent JM and Cooney KA. Genome-wide scan for prostate cancer susceptibility genes using families from the University of Michigan prostate cancer genetics project finds evidence for linkage on chromosome 17 near BRCA7. Prostate 2003; 57 (4): 326-334.

66. Schleutker J, Baffoe-Bonnie AB, Gillanders E, Kainu T, Jones MP, Freas-Lutz D, Markey C, Gildea D, Riedesel E, Albertus J, Gibbs KD Jr, Matikainen M, Koivisto PA, Tammela T, Bailey-Wilson JE, Trent $J M$ and Kallioniemi OP. Genome-wide scan for linkage in Finnish hereditary prostate cancer (HPC) families identifies novel susceptibility loci at 11 q14 and 3p25-26. Prostate 2003; 57 (4): 280-289.

67. Cunningham JM, McDonnell SK, Marks A, Hebbring S, Anderson SA, Peterson BJ, Slager S, French A, Blute ML, Schaid DJ, Thibodeau SN; Mayo Clinic, Rochester, Minnesota. Genome linkage screen for prostate cancer susceptibility loci: results from the Mayo Clinic Familial Prostate Cancer Study. Prostate 2003; 57 (4): 335-346.

68. Xu J, Gillanders EM, Isaacs SD, Chang BL, Wiley KE, Zheng SL, Jones M, Gildea D, Riedesel E, Albertus J, Freas-Lutz D, Markey C, Meyers DA, Walsh PC, Trent JM and Isaacs WB. Genome-wide scan for prostate cancer susceptibility genes in the Johns Hopkins hereditary prostate cancer families. Prostate 2003; 57 (4): 320-325.

69. Wiklund F, Gillanders EM, Albertus JA, Bergh A, Damber JE, Emanuelsson M, Freas-Lutz DL, Gildea DE, Goransson I, Jones MS, Jonsson BA, Lindmark F, Markey CJ, Riedesel EL, Stenman E, Trent JM and Gronberg H. Genome-wide scan of Swedish families with hereditary prostate cancer: suggestive evidence of linkage at $5 q 11.2$ and 19p13.3. Prostate 2003; 57 (4): 290-7.

70. Janer M FD, Stanford JL, Badzioch MD, Kolb S, Deutsch K, Peters MA, Goode EL, Welti R, DeFrance HB, Iwasaki L, Li S, Hood L, Ostrander EA and Jarvik GP. Genomic scan of 254 hereditary prostate cancer families. Prostate 2003; 57 (4): 309-319.

71. Witte JS, S. B., Thiel B, Lin J, Yu A, Banerjee TK, Burmester JK, Casey $G$ and Catalona WJ. Genome-wide scan of brothers: replication and fine mapping of prostate cancer susceptibility and aggressiveness loci. Prostate 2003; 57 (4): 298-308.

72. The International ACTANE Consortium. Results of a genome-wide linkage analysis in prostate cancer families ascertained through the ACTANE consortium. Prostate 2003; 57 (4): 270-279.

73. Gronberg H, Smith J, Emanuelsson M, Jonsson BA, Bergh A, Carpten J, Isaacs W, Xu J, Meyers D, Trent J and Damber JE. In Swedish families with hereditary prostate cancer, linkage to the $\mathrm{HPCl}$ locus on chromosome 1q24-25 is restricted to families with earlyonset prostate cancer. Am J Hum Genet 1999; 65 (1): 134-140.

74. Cooney KA, McCarthy JD, Lange E, Huang L, Miesfeldt S, Montie JE, Oesterling JE, Sandler HM and Lange K. Prostate cancer susceptibility locus on chromosome 1q: a confirmatory study. J Natl Cancer Inst 1997; 89 (13): 955-959.

75. Neuhausen SL, Farnham JH, Kort E, Tavtigian SV, Skolnick MH and Cannon-Albright LA. Prostate cancer susceptibility locus HPC 1 in Utah high-risk pedigrees. Hum Mol Genet 1999; 8 (13): 2437 2442.

76. Xu J, Zheng SL, Chang B, Smith JR, Carpten JD, Stine OC, Isaacs SD, Wiley KE, Henning L, Ewing C, Bujnovszky P, Bleeker ER, Walsh PC, Trent JM, Meyers DA and Isaacs WB. Linkage of prostate cancer susceptibility loci to chromosome 1. Hum Genet 2001; 108 (4): 335-345. Epub 28 March 2001

77. Mclndoe RA, Stanford JL, Gibbs M, Jarvik GP, Brandzel S, Neal CL, Li S, Gammack JT, Gay AA, Goode EL, Hood L and Ostrander EA. Linkage analysis of 49 high-risk families does not support a common familial prostate cancer-susceptibility gene at 1q24-25. Am J Hum Genet 1997; 61 (2): 347-353.

78. Eeles RA, Durocher F, Edwards S, Teare D, Badzioch M, Hamoudi R, Gill S, Biggs P, Dearnaley D, Ardern-Jones A, Dowe A, Shearer R, McLennan DL, Norman RL, Ghadirian P, Aprikian A, Ford D, Amos C, King TM, Labrie F, Simard J, Narod SA, Easton D and 
Foulkes WD. Linkage analysis of chromosome $1 \mathrm{q}$ markers in 136 prostate cancer families. The Cancer Research Campaign/British Prostate Group U.K. Familial Prostate Cancer Study Collaborators. Am J Hum Genet 1998; 62 (3): 653-658.

79. Goddard KA, Witte JS, Suarez BK, Catalona WJ and Olson JM. Model-free linkage analysis with covariates confirms linkage of prostate cancer to chromosomes 1 and 4. Am J Hum Genet 2001; 68 (5): 1197-206. Epub 2001 Apr 13.

80. $\mathrm{Xu} \mathrm{J.} \mathrm{Combined} \mathrm{analysis} \mathrm{of} \mathrm{hereditary} \mathrm{prostate} \mathrm{cancer} \mathrm{linkage}$ to 1q24-25: results from 772 hereditary prostate cancer families from the International Consortium for Prostate Cancer Genetics. Am J Hum Genet 2000; 66 (3): 945-957. Erratum in: Am J Hum Genet 2000; 67 (2): 541-542.

81. Carpten J, Nupponen N, Isaacs S, Sood R, Robbins C, XU J, Faruque M, Moses T, Ewing C, Gillanders E, Hu P, Bujnovszky P, Makalowska I, Baffoe-Bonnie A, Faith D, Smith J, Stephan D, Wiley K, Brownstein M, Gildea D, Kelly B, Jenkins R, Hostetter G, Matikainen M, Schleutker J, Klinger K, Connors T, Xiang Y, Wang Z, De Marzo A, Papadopoulos N, Kallioniemi OP, Burk R, Meyers D, Gronberg H, Meltzer P, Silverman R, Bailey-Wilson J, Walsh P, Isaacs W and Trent J. Germline mutations in the ribonuclease $\mathrm{L}$ gene in families showing linkage with $\mathrm{HPC} 1$. Nat Genet 2002; 30 (2): 181-4. Epub 2002 Jan 22.

82. Rokman A, I. konen T, Seppala EH, Nupponen N, Autio V, Mononen N, Bailey-Wilson J, Trent J, Carpten J, Matikainen MP, Koivisto PA, Tammela TL, Kallioniemi OP and Schleutker J. Germline alterations of the RNASEL gene, a candidate HPC 1 gene at 1q25, in patients and families with prostate cancer. Am J Hum Genet 2002; 70 (5): 1299-304. Epub 2002 Apr 08. Erratum in: Am J Hum Genet 2002 Jul; 71 (1): 215.

83. Casey G, Neville PJ, Plummer SJ, Xiang Y, Krumroy LM, Klein EA, Catalona WJ, Nupponen N, Carpten JD, Trent JM, Silverman $\mathrm{RH}$ and Witte JS. RNASEL Arg462GIn variant is implicated in up to $13 \%$ of prostate cancer cases. Nat Genet 2002; 32 (4): 581-583. Epub 2002 Nov 04.

84. Chen H, Griffen AR, Wu YQ, Tomsho LP, Zuhlke KA, Lange EM, Gruber SB and Cooney KA. RNASEL mutations in hereditary prostate cancer. J Med Genet 2003; 40 (3): e21.

85. Wang L, McDonnel SK, Cunningham JM, Hebbring S, Jacobsen SJ, Cerhan JR, Slager SL, Blute ML, Schaid DJ and Thibodeau SN. No association of germline alteration of MSRT with prostate cancer risk. Nat Genet 2003; 35 (2): 128-129. Epub 2003 Sep 07.

86. Meitz JC, Edwards SM, Easton DF, Murkin A, Ardern-Jones A, Jackson RA, Williams S, Dearnaley DP, Stratton MR, Houlston RS, Eeles RA; Cancer Research UK/BPG UK Familial Prostate Cancer Study Collaborators. HPC2/ELAC2 polymorphisms and prostate cancer risk: analysis by age of onset of disease. $\mathrm{Br} \mathrm{J}$ Cancer 2002; 87 (8): 905-908.

87. Badzioch M, Eeles R, Leblanc G, Foulkes WD, Giles G, Edwards S, Goldgar D, Hopper JL, Bishop DT, Moller P, Heimdal K, Easton $D$ and Simard J. Suggestive evidence for a site specific prostate cancer gene on chromosome 1p36. The CRC/BPG UK Familial Prostate Cancer Study Coordinators and Collaborators. The EU Biomed Collaborators. J Med Genet 2000; 37 (12): 947-949.

88. Xu J, Meyers D, Freije D, Isaacs S, Wiley K, Nusskern D, Ewing C, Wilkens E, Bujnovszky P, Bova GS, Walsh P, Isaacs W, Schleutker J, Matikainen M, Tammela T, Visakorpi T, Kallioniemi OP, Berry R, Schaid D, French A, McDonnell S, Schroeder J, Blute M, Thibodeau $\mathrm{S}$, Trent J, et al. Evidence for a prostate cancer susceptibility locus on the X chromosome. Nat Genet 1998; 20 (2): 175-179.

89. Witte JS, Goddard KA, Conti DV, Elston RC, Lin J, Suarez BK, Broman KW, Burmester JK, Weber JL and Catalona WJ. Genomewide scan for prostate cancer-aggressiveness loci. Am J Hum Genet 2000; 67 (1): 92-99. Epub 2000 May 24.
90. Slager SL, Schaid DJ, Cunningham JM, McDonnell SK, Marks AF, Peterson BJ, Hebbring SJ, Anderson S, French AJ and Thibodeau SN. Confirmation of linkage of prostate cancer aggressiveness with chromosome 19q. Am J Hum Genet 2003; 72 (3): 759-762. Epub 2003 Jan 30.

91. Neville PJ, Conti DV, Krumroy LM, Catalona WJ, Suarez BK, Witte JS and Casey G. Prostate cancer aggressiveness locus on chromosome segment 19q12-q13.1 identified by linkage and allelic imbalance studies. Genes Chromosomes Cancer 2003; 36 (4): 332-339.

92. Irvine RA, Yu MC, Ross RK and Coetzee GA. The CAG and GGC microsatellites of the androgen receptor gene are in linkage disequilibrium in men with prostate cancer. Cancer Res 1995; 55: 1937-1940.

93. Hardy DO, Scher HI, Bogenreider T, Sabbatini P, Zhang ZF, Nanus DM and Catterall JF. Androgen receptor CAG repeat lengths in prostate cancer: correlation with age of onset. J Clin Endocrinol Metab 1996; 81: 4400-4405.

94. Ingles SA, Ross RK, Yu MC, Irvine RA, La Pera G, Haile RW and Coetzee GA. Association of prostate cancer risk with genetic polymorphisms in vitamin D receptor and androgen receptor. J Natl Cancer Inst 1997; 89: 166-170.

95. Stanford JL, Just JJ, Gibbs M, Wicklund KG, Neal CL, Blumenstein BA and Ostrander EA. Polymorphic repeats in the androgen receptor gene: molecular markers of prostate cancer risk. Cancer Res 1997; 57: 1194-1198.

96. Giovannucci E, Stampfer MJ, Krithivas K, Brown M, Dahl D, Brufsky A, Talcott J, Hennekens CH and Kantoff PW. The CAG repeat within the androgen receptor gene and its relationship to prostate cancer. Proc Natl Acad Sci USA 1997; 94: 3320-3323.

97. Hakimi JM, Schoenberg MP, Rondinelli RH, Piantadosi S and Barrack ER. Androgen receptor variants with short glutamine or glycine repeats may identify unique subpopulations of men with prostate cancer. Clin Cancer Res 1997; 3: 1599-1608.

98. Miller EA, Stanford JL, Hsu L, Noonan E and Ostrander EA. Polymorphic repeats in the androgen receptor gene in high-risk sibships. Prostate 2001; 48: 200-205.

99. Hsing AW, Gao YT, Wu G, Wang X, Deng J, Chen YL, Sesterhenn IA, Mostofi FK, Benichou J and Chang C. Polymorphic CAG and GGN repeat lengths in the androgen receptor gene and prostate cancer risk: a population-based case-control study in China. Cancer Res 2000; 60: 5111-5116.

100. Edwards SM, Badzioch MD, Minter R, Hamoudi R, Collins N, Ardern-Jones A, Dowe A, Osborne S, Kelly J, Shearer R, Easton DF, Saunders GF, Dearnaley DP and Eeles RA. Androgen receptor polymorphisms: association with prostate cancer risk, relapse and overall survival. Int J Cancer 1999; 84: 458-465.

101. Makridakis NM, Ross RK, Pike MC, Crocitto LE, Kolonel LN, Pearce CL, Henderson BE and Reichardt JK. Association of mis-sense substitution in SRD5A2 gene with prostate cancer in African-American and Hispanic men in Los Angeles, USA. Lancet 1999; 354: 975-978.

102. Kote-Jarai Z, Easton D, Edwards SM, Jefferies S, Durocher F, Jackson RA, Singh R, Ardern-Jones A, Murkin A, Dearnaley DP, Shearer R, Kirby R, Houlston R, Eeles R; CRC/BPG UK Familial Prostate Cancer Study Collaborators. Relationship between glutathione S-transferase $\mathrm{Ml}, \mathrm{Pl}$ and $\mathrm{T} 1$ polymorphisms and early onset prostate cancer. Pharmacogenetics 2001; 1 1: 325-330.

103. Parkes C, Wald NJ, Murphy P, George L, Watt HC, Kirby R, Knekt P, Helzlsover KJ and Tuomilehto J. Prospective observational study to assess value of prostate specific antigen as screening test for prostate cancer. BMJ 1995; 311 (7016): 1340-1343.

104. Walsh PC. Hereditary Prostate Cancer, podium talk at the annual meeting of the American Society of Clinical Oncology, 1996. 
105. Kupelian PA, Klein EA, Witte JS, Kupelian VA and Suh JH. Familial prostate cancer: a different disease? J Urol 1997; 158 (6): 2197-2201.

106. Valeri A, Azzouzi R, Drelon E, Delannoy A, Mangin P, Fournier $G$, Berthon $P$ and Cussenot $O$. Early-onset hereditary prostate cancer is not associated with specific clinical and biological features. Prostate 2000; 45 (1): 66-71.

107. Bova GS, Partin AW, Isaacs SD, Carter BS, Beaty TL, Isaacs WB and Walsh PC. Biological aggressiveness of hereditary prostate cancer: long-term evaluation following radical prostatectomy. J Urol 1998; 160 (3 Pt 1): 660-663.

108. Kupelian PA, Kupelian VA, Witte JS, Macklis R and Klein EA. Family history of prostate cancer in patients with localized prostate cancer: an independent predictor of treatment outcome. J Clin Oncol 1997; 15: 1478.

109. Cussenot O, Valeri A, Berthon P, Fournier G and Mangin P. Hereditary prostate cancer and other genetic predispositions to prostate cancer. Urol Int 1998; 60 Suppl 2: 30-4; discussion 35. Review.

110. American Urological Association, Prostate Cancer Awareness For Men: A Doctor's Guide for Patients 2001; pages 4-5.

111. Cancer Reference Information: Can Prostate Cancer Be Found Early? American Cancer Society. October 3, 2001.

1 12. Hanlon AL and Hanks GE. Patterns of inheritance and outcome in patients treated with external beam radiation for prostate cancer. Urology 1998; 52 (5): 735-738.

113. Lieberman R. Chemoprevention of prostate cancer: current status and future directions. Cancer Metastasis Rev 2002; 21 (3-4): 297-309.

1 14. Clark LC, Dalkin B, Krongrad A, Combs GF Jr, Turnbull BW, Slate EH, Witherington R, Herlong JH, Janosko E, Carpenter D, Borosso C, Falk S and Rounder J. Related Articles, Links. Decreased incidence of prostate cancer with selenium supplementation: results of a double-blind cancer prevention trial. Br J Urol 1998; 81 (5): 730-734.

115. Klein EA and Thompson IM. Update on chemoprevention of prostate cancer. Curr Opin Urol 2004; 14 (3): 143-149.

116. Klein EA. Clinical models for testing chemopreventative agents in prostate cancer and overview of SELECT: the Selenium and Vitamin E Cancer Prevention Trial. Recent Results Cancer Res 2003; 163: 212-25; discussion 264-6. Review.

117. Kommu S, Sharifi R., Edwards S and Eeles R. Proteomics and urine analysis - a potential promising new tool in urology. BJU Int 2004; 93 (9): 1172-1173.

1 18. McWhorter WP, Hernandez AD, Meikle AW, Terreros DA, Smith JA Jr, Skolnick MH, Cannon-Albright LA and Eyre HJ. A screening study of prostate cancer in high risk families. J Urol 1992; 148 (3): 826-828.

119. Tischkowitz M, Eeles R; IMPACT study: Identification of Men with genetic predisposition to Prostate Cancer and its Clinical Treatment collaborators. Mutations in BRCA1 and BRCA2 and predisposition to prostate cancer. Lancet 2003; 362 (9377): 80; author reply 80.

120. Blueggel M, Chamrad D and Meyer HE. Bioinformatics in proteomics. Curr Pharm Biotechnol 2004; 5 (1): 79-88. Review. i 